\title{
Index futures trading, information and stock market volatility: The case of Greece
}

\author{
Christos Floros* and Dimitrios V. Vougas** \\ * Department of Economics, University of Portsmouth, Portsmouth Business School, \\ Portsmouth, PO1 3DE, UK. Tel: +44 (0)2392 844244; \\ E-mail: Christos.Floros@port.ac.uk \\ **Department of Economics, University of Wales Swansea, Singleton Park, Swansea \\ SA2 8PP, UK \\ Tel: +44 (0)1792 602102; E-mail: d.v.vougas@swan.ac.uk
}

Received: (in revised form) 4th May, 2006

Christos Floros completed his first degree in mathematics and operational research at Brighton University and also holds MA (economics) and MSc (mathematics) degrees from Portsmouth University and a PhD in financial economics from Swansea University. He is a lecturer in banking and finance at the University of Portsmouth and his research interests include financial econometrics, derivatives and banking efficiency.

Dimitrios V. Vougas studied economics and econometrics at the Athens University of Economics and Business and the University of Bristol with a scholarship from the State Scholarship Foundation of Greece. He lectures at Swansea University and previously held a research position at the University of Nottingham and lecturing positions at Middlesex and Portsmouth universities.

\section{Practical applications}

The introduction of a futures market and, in particular, the impact of futures on stock market volatility is a long debate. Previous studies show that the futures market leads to an increase in market depth and a decrease in volatility. This is due to the more rapid rate at which information is reflected in prices and speculation. Other studies suggest that a decrease in cash market volatility is due to an increase in market liquidity. Empirical studies for UK and US financial markets do not conclude clearly whether the introduction of futures stabilises or destabilises the underlying spot market. It is therefore important for practitioners to look at the link between information (news) and volatility. To the authors' knowledge, this is the first study that examines this effect of the Greek futures market on stock market volatility.

\section{Abstract}

This paper examines the effect of futures trading on the volatility of the underlying spot market. It focuses on various techniques to investigate the relationship between information and the volatility of the FTSE/ASE-20 and
FTSE/ASE Mid 40 indices in Greece. The results for the FTSE/ASE-20 index suggest that futures trading has led to decreased stock market volatility (negative effect), but the results for the FTSE/ASE Mid 40 index indicate that the introduction of stock index futures has led to
Derivatives Use, Trading \& Regulation Vol. 12 No. $1 / 2,2006$ pp. 146-166 (c) Palgrave Macmillan Ltd Ltd $1747-4426 / 06 \$ 30.00$ 
increased volatility (positive effect), while the estimations of the unconditional variances indicate lower market volatility after the introduction of stock index futures. Furthermore, the results show that good news has a more rapidly impact on FTSE/ASE-20 stock return volatility. For the FTSE/ASE Mid 40 index, the results suggest that news is reflected in prices more slowly, while old news has a less persistent effect on prices. These findings are helpful to financial managers dealing with Greek stock index futures.

\section{INTRODUCTION}

The debate on the impact of futures on stock market volatility is still controversial. In other words, the issue of whether the futures markets affect underlying spot markets is not widely accepted. Some past critics of index futures agree that the introduction of stock index futures increases stock market volatility. Others report no significant volatility effect associated with the introduction of stock index futures. In general, the link between futures trading and stock market volatility has become very complex. Several studies have empirically examined the long-term relationship across the decades. Most of them compare the volatility of the spot market before and after the introduction of futures trading, using econometric models. According to Bologna and Cavallo, ${ }^{1}$ there are two theories in the literature about the relationship between futures markets and underlying spot markets. The first theory supports the argument that futures trading destabilises the underlying spot market by increasing its volatility. In practice, volatility increases through speculation or arbitrage strategies. Then, an increase in interest rates and the cost of capital, leading to a reduction in the value of investments, is quite possible. From a financial viewpoint, the price volatility usually depends on the arrival of new information in the market. If the market is efficient, the price reflects this new information, but the literature presents arguments that futures markets increase market depth ${ }^{2}$ and reduce spot market volatility. One possible explanation why futures markets reduce the spot market volatility is financial risk.

The majority of papers in the literature consider the effect of futures trading on stock market volatility using either an unconditional measure of volatility or GARCH models. GARCH models spot and futures market volatility. This paper uses both techniques. In addition, most of papers in the literature look at data from highly developed markets such as the US and UK.

This paper examines two newly introduced Greek stock index futures on the FTSE/ASE-20 and FTSE/ASE Mid 40. It addresses any stabilisation/destabilisation effects and the impact of futures trading on the associated stock market indices. In this respect, the findings are very important in the absence of any previous work examining the effect of futures trading on the Greek spot index markets.

The plan of the paper is as follows. In the second section, the theoretical debate and literature review are presented. The third section outlines the methodology, while the fourth section describes the data. The fifth section presents empirical results 
from various econometric models, and the final section concludes the paper and summarises the findings.

\section{THEORETICAL DEBATE AND LITERATURE REVIEW}

Futures contracts are attractive to investors and speculators because they have low margin requirements and low transaction costs. The above does not imply, however, that futures are destabilising. Apparently, several theoretical arguments have been used over the years to explain why derivatives markets in general might affect the volatility of the spot market (the underlying asset market). Theoretically, when futures are introduced, one can buy or sell futures, options, commodities or other products. This may influence spot prices, if the producers respond to new information. Various information-based models analyse and explain whether the opening of a futures market may stabilise or destabilise stock prices. This literature includes papers by Stein, ${ }^{3}$ Subrahmanyam ${ }^{4}$ and Newbery. ${ }^{5}$

In addition, according to Chari et al. ${ }^{6}$ futures markets may stabilise or destabilise prices. Since futures and spot prices are usually closely related, futures are attractive to speculators. Antoniou and Holmes ${ }^{7}$ argue that the arrival of futures trading depends on speculators' information. In other words, when speculators have perfect information, the introduction of futures markets stabilises prices. But when speculators have a noisy signal, there is a destabilising effect. In some cases, however, the introduction of a futures contract leads to a more stable spot price.
Since futures markets have a higher degree of leverage than cash markets do, they are more likely to attract uninformed speculative investors and thus destabilise cash markets by increasing volatility. But futures markets increase the overall market depth and informativeness, are important for price discovery, allow the transfer of risk and may actually reduce spot volatility.

Index futures contracts have several advantages over the underlying stock index. These enable holders to trade on accessible credit and reduce costs using several strategies. Index futures have some disadvantages, however, such as a non-beneficial increase in price variability; see Hodgson and Nicholls. ${ }^{8}$

Several studies examine the relationship and behaviour between stock market volatility and index futures volatility. For instance, Edwards ${ }^{9}$ examines stock market volatility before and after the introduction of futures. He finds that the introduction of the S\&P500 futures contract has reduced cash market volatility. Hodgson and Nicholls, ${ }^{8}$ however, examine the effect of index futures on Australian sharemarket volatility, and argue that the introduction of trading in index futures has not affected the long-term volatility of the underlying spot share market. Further, Chang et al. ${ }^{10}$ point out that futures trading increases spot portfolio volatility (with no volatility spillovers). In addition, Aggarwal ${ }^{11}$ and Harris $^{12}$ find that the post-futures period is more volatile. Harris ${ }^{12}$ reports that the volatility of S\&P500 stocks increased, relative to the volatility of stocks in a control system. Also, Lockwood and Lim ${ }^{13}$ find that cash stock market volatility 
increased after stock index futures trading. Also, Maberly et al. ${ }^{14}$ find that volatility increased in the S\&P500 index.

Further, for the New York Stock Exchange (NYSE), Chang et al. ${ }^{15}$ examine the effects on futures volatility and price changes. Empirical results show that there is an increase in volatility only at the close of the futures market. By contrast, when the NYSE closes, volatility falls significantly. Another interesting point is that higher volatility in the spot market increases the demand for further hedging in stock index futures. $^{16}$

Since analysis of the introduction of index futures usually depends on the choice of pre- and post-futures periods, ${ }^{14}$ the effect of future trading on volatility can be modelled using GARCH-family models. Specifically, one can examine whether the existence of futures trading has any effect on volatility, using a conditional variance model with a dummy variable.

First, Chan et al. ${ }^{17}$ examine the intra-day volatility spillovers between S\&P500 index stock and futures markets using GARCH models and show a strong cross-market dependence in the volatility process. Then, Antoniou and Foster ${ }^{18}$ analyse the effect of futures trading on Brent crude oil spot price volatility (for 1988). From GARCH analysis, they find an increase in informational spot market efficiency and a decrease in the old-news term.

Another approach is by Antoniou and Holmes. ${ }^{7}$ They use GARCH models to examine the relationship between trading, information and volatility in the FTSE 100 stock index futures (using data from November 1980 to October 1991). They argue that it is better to model the volatility following a GARCH $(1,1)$ process as the conditional variance of the error term is a linear function. Hence, they use a GARCH $(1,1)$ process with a dummy variable to investigate the impact of futures trading on spot market volatility. Their results show that the volatility of the spot market with futures is greater than that without futures. For the whole period, the analysis with GARCH $(1,1)$ suggests that there is an increase in spot price volatility on futures. For the sub-periods, the GARCH parameters are significantly different from zero and, also, for both preand post-futures trading there is an increase in the unconditional variance, and therefore an increase in volatility and a definite impact of trading in futures on spot price volatility has been found. Furthermore, Brorsen $^{19}$ and Gulen and Mayhew ${ }^{20}$ suggest that volatility increases in many markets. Gulen and Mayhew ${ }^{20}$ examine stock market volatility before and after the introduction of equity index futures trading in 25 countries using the GJR-GARCH, the Non-linear GARCH and the EGARCH models. In addition, Holmes ${ }^{21}$ examines the impact of FTSE Eurotrack futures trading on spot volatility using daily closing price indices for the period June 1990-April 1994. His results show that futures contracts have a beneficial impact on price discovery in the spot market, even when traded market is thin. By contrast, Robinson ${ }^{22}$ provides evidence of a stabilising effect of futures trading activity on the volatility of the FTSE 100 index. Antoniou et al., ${ }^{23}$ however, examine further the impact of futures trading on FTSE 100 stock index 
volatility. Now using the GJR-GARCH $(1,1)$ model with a dummy variable, they conclude that futures trading has a negative impact on the volatility of the stock market. Further, Butterworth ${ }^{24}$ examines the link between volatility and news for the FTSE Mid 250 index using symmetric and asymmetric GARCH methods. He argues that the new information after the onset of futures is reflected in prices less rapidly and, therefore, an increase in the persistence of volatility is quite possible.

In addition, Rahman ${ }^{25}$ examines the impact of index futures trading on the volatility of component stocks for the Dow Jones Industrial Average (DJIA). The data cover the period April-June 1997 (pre-futures) and April-June 1998 (post-futures). Rahman ${ }^{25}$ uses the simple GARCH $(1,1)$ model to estimate the conditional volatility of intra-day returns. The empirical results confirm that there is no change in conditional volatility from pre- and post-futures periods.

Another good representation for volatility modelling is the EGARCH model. Koutmos and Tucker ${ }^{26}$ use the EGARCH model and show that, for both stock and futures markets, bad news increases volatility more than good news. Further, Pericli and Koutmos ${ }^{27}$ use an EGARCH model and find that the volatility of the S\&P500 index has decreased after the introduction of futures trading (for S\&P500). Darrat et al. ${ }^{28}$ examine the volatility and test the relationships between volatilities in the spot and futures markets. The sample spans the period after the stock market crash of October 1987 (ie November 1987-November 1997). They use an EGARCH model to measure spot returns volatility and futures returns volatility. According to their empirical results, 'futures trading is not responsible for cash market volatility'. Therefore, a possible explanation is that an unstable spot market could affect volatility in the index futures market.

Further, Lien and $\mathrm{Tse}^{29}$ examine the effect and the relationship between cash settlement and cash-futures prices using a bivariate GARCH model with a dummy variable (for measuring those effects). Their empirical results show that the futures market leads the cash market and that the cash settlement has never had an impact on cash and futures returns (ie the coefficient of the dummy variable is found to be statistically insignificant). In addition, Kyriacou and Sarno ${ }^{30}$ examine the relationship between UK spot market volatility and futures trading using the GARCH process. The time series spans from 1 October 1992 to 29 December 1995. The empirical results suggest that spot market volatility could be modelled by a GARCH $(1,1)$, and volatility is characterised as statistically reliable. Kyriacou and Sarno ${ }^{30}$ argue that futures trading affects spot market volatility in 'opposite directions'.

Gulen and Mayhew ${ }^{20}$ examine the time series behaviour of stock indices for 25 countries, using several GARCH models. As they point out, in the US and Japan, futures trading leads to an increase in conditional volatility. Bologna and Cavallo ${ }^{1}$ examine the effect of the introduction of stock index futures, that is whether it reduces stock market volatility (for Italian 
market). Their empirical results show that the introduction of stock index futures affects the volatility of the spot market. Also, the results from $\operatorname{GARCH}(1,1)$ models - for pre-futures and post-futures sub-periods - suggest that the index futures market reduces volatility. In addition, the 'old news' parameter from the presence of stock index futures trading has had a different (less) impact for stock market volatility estimation.

Pilar and Rafael ${ }^{31}$ analyse the effect of the introduction of futures in the Spanish stock market using a GJR model. The results indicate a decrease in volatility after the introduction of futures. Another empirical approach on the effect of futures trading on volatility is that from

Figuerola-Ferretti and Gilbert. ${ }^{32}$ They use Aluminium transaction prices to examine whether futures trading affects volatility. To do so, they use error-correction models and the $\operatorname{GARCH}(1,1)$ regression model. In addition, they report the results of a VAR model and display impulse response analysis to track the effects of a shock to each of the volatilities. Their results show that volatility decreases in the post-period.

Chiang and Wang ${ }^{33}$ examine the impact of futures trading on Taiwan spot index volatility. This study also discusses the macroeconomic effects on spot volatility and the asymmetric effects of futures trading on spot price volatility behaviour. The data cover the period from 5 January 1995 to 10 March 2000. The asymmetric time-varying GJR volatility model is employed. Their empirical results show that futures trading of Taiwan Index Futures has major impacts on spot price volatility, while the trading of MSCI Taiwan futures has no effects except the asymmetric response behaviour. Bae et al. ${ }^{34}$ examine the effect of the introduction of index futures trading in the Korean markets on spot price volatility. The results show that there is an increase in spot price volatility after the introduction of futures trading. These findings are in line with Ryoo and Smith ${ }^{35}$ for the Korean market. They find that futures trading increases the speed at which information is reflected in spot market prices, reduces the persistence of information and increases spot market volatility. Recently, Antoniou et al. ${ }^{36}$ test the hypothesis that the introduction of index futures has increased positive feedback trading in the spot markets of six industrialised nations. Their findings support the view that futures markets help stabilise the underlying spot markets by reducing the impact of feedback traders and attracting more rational investors.

Overall, it is evident that the majority of studies discussed conclude that futures may have either a positive or a negative impact on stock market volatility. Also, a decrease or increase in volatility after the introduction of futures is found. Hence, the debate on the impact of futures trading on stock market volatility does not give clear conclusions.

To analyse the impact of futures trading on Greek stock market volatility, several GARCH models are estimated for both sub-periods, thereby allowing a comparison of volatility before and after the introduction of futures trading. Several GARCH models are used to find which model fits the data best. Also, one needs to know how these GARCH specifications model volatility before and after the 
introduction of futures trading. Notice that GARCH models link information (news) to volatility.

\section{METHODOLOGY}

Past empirical papers show that the effect of future trading on volatility can be modelled using conditional variance models. In other words, one can examine whether the existence of futures trading has any effect on volatility by using a $(\mathrm{GARCH})$ volatility model with a dummy variable (taking the value zero pre-futures and one post-futures). If the dummy is statistically significant, the existence of futures trading has an impact on spot market volatility (see Antoniou et al. ${ }^{23}$ ).

Many studies analyse the 'futures effect' using the standard $\operatorname{GARCH}(1,1)$ model $^{1,24}$ or the GJR model, which tests for the presence of asymmetries. ${ }^{23,24,31}$

To analyse the effect of future trading on stock market volatility, GARCH models are also employed. The $\operatorname{GARCH}(p, q)$ model captures better the tendency of returns to exhibit volatility clustering, incorporating heteroscedasticity into the estimation procedure. In this model, positive and negative past values have a symmetric effect on the conditional variance. The standard GARCH $(1,1)$ model with dummy variable can be expressed as follows

$$
\begin{aligned}
& R_{t}=\mu+\varepsilon_{t} \\
& \sigma_{t}^{2}=\omega+a_{1} \varepsilon_{t-1}^{2}+\beta_{1} \sigma_{t-1}^{2}+c D_{i}+u
\end{aligned}
$$

The dummy variable $D_{i}$ takes zero value for the pre-futures period and one for the post-futures period. This dummy allows one to determine whether futures prices are related to any change in the spot market volatility. When the coefficient of the dummy variable is positive (negative), there is a positive (negative) effect of futures trading on volatility. In addition, assuming that markets are efficient, $a_{1}$ (the ARCH parameter) can be viewed as a 'news' coefficient, while $\beta_{1}$ (the GARCH parameter) can be viewed as 'old news' and the persistence coefficient (see Antoniou and Holmes ${ }^{7}$ ). Furthermore, according to Butterworth $^{24}$, an increase (decrease) in $a_{1}$ suggests that news is reflected in prices more rapidly (slow). A reduction in $\beta_{1}$ suggests that old news has a less persistent effect on prices changes. In addition, an increase in $\beta_{1}$ suggests greater persistence. Also, when the sum $a_{1}+\beta_{1}$ approaches unity, volatility shocks are persistent.

Other specifications of the $\operatorname{GARCH}(p, q)$ include the exponential GARCH (EGARCH) and threshold GARCH (TGARCH). Both models capture volatility asymmetry.

- EGARCH model. The variance equation of Exponential GARCH $(1,1)$ model with a dummy variable is the following

$$
\begin{aligned}
\log \left(\sigma_{t}^{2}\right)= & \omega+a_{1}\left|\frac{\varepsilon_{t-1}}{\sigma_{t-1}}\right|+a_{2} \frac{\varepsilon_{t-1}}{\sigma_{t-1}} \\
& +a_{3} \log \left(\sigma_{t-1}^{2}\right)+c D_{i}
\end{aligned}
$$

- TGARCH(1,1) model. The variance equation with a dummy variable is given by

$$
\begin{aligned}
\sigma^{2}{ }_{t}= & \omega+a_{1} \varepsilon_{t-1}^{2}+a_{2} \varepsilon_{t-1}^{2} d_{t-1} \\
& +a_{3} \sigma_{t-1}^{2}+c D_{i}
\end{aligned}
$$


Table 1: Statistics for FTSE/ASE-20 log returns

\begin{tabular}{lrrr} 
Sample period & N & \multicolumn{1}{l}{ Mean } & \multicolumn{1}{l}{ SD } \\
& & & \\
Pre-futures & 502 & 0.002084 & 0.024643 \\
Post-futures & 500 & -0.001346 & 0.019884 \\
\hline
\end{tabular}

Table 2: Statistics for FTSE/ASE Mid 40 log returns

$\begin{array}{llll}\text { Sample period } & N & \text { Mean } & \text { SD } \\ & & & \\ \text { Pre-futures } & 36 & -0.003228 & 0.037806 \\ \text { Post-futures } & 393 & -0.002826 & 0.023835\end{array}$

Table 3: Results of GARCH models for FTSE/ASE-20 index

$\begin{array}{lll}\text { Model } & \begin{array}{l}\text { Coeff. on } \\ \text { dummy }\end{array} & \text { t-ratio } \\ \text { MA(1)-TGARCH } & -5.48 \mathrm{E}-05 & -2.0743 \star \\ \text { MA(1)-GARCH }(1,1) & -5.34 \mathrm{E}-05 & -2.1660^{\star} \\ \text { MA(1)-EGARCH } & -0.1070 & -1.9461^{\star} \\ \text { GARCH }(1,1) & -5.71 \mathrm{E}-05 & -2.2703^{\star} \\ \text { EGARCH } & -0.1134 & -2.1201^{\star} \\ \text { TGARCH } & -6.06 \mathrm{E}-05 & -2.2261^{\star}\end{array}$

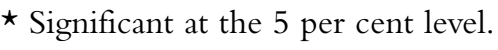

Good news $\left(\varepsilon_{t}<0\right)$ and bad news $\left(\varepsilon_{t}>0\right)$ have an impact on $a_{1}$ and $a_{1}+a_{2}$, respectively. In other words, a negative innovation (shock) has a greater impact than a positive innovation on volatility.
Also when $a_{2}>0$, the leverage effect exists. When $a_{2} \neq 0$ and significant, the news impact is asymmetric.

The methodology is based on the following two parts: First, we test for the impact of futures trading on stock market volatility using the above models with a dummy variable. The next step consists of examining and comparing the volatility parameters across two sub-periods: the pre-futures period and the post-futures period. GARCH models are estimated with the Marquardt algorithm, using the Heteroscedasticity Consistent Covariance option (see also Floros and Vougas ${ }^{37}$ ). The conditional mean of the data is also estimated using $\operatorname{ARMA}(p, q)$ models (when necessary). Both orders are determined by the AIC. Finally, the unconditional variance is also estimated.

\section{DATA DESCRIPTION}

Daily closing prices for the FTSE/ASE-20 index are used over the period September 1997-July 2001. For the FTSE/ASE Mid 40 index, the daily closing prices are used over the period December 1999-July 2001. Closing prices for stock indices were obtained from Datastream.

Next, the main statistics (mean and standard deviations) of the returns for the sub-periods before and after the introduction of futures trading are reported. Table 1 contains information for the FTSE/ASE-20 index, and Table 2 for the FTSE/ASE Mid 40 index.

It is clear that daily standard deviations (SD) have changed little. For both periods before and after the introduction of futures 
Table 4: FTSE/ASE-20 index

A. Pre-futures period: $M A(1)-T G A R C H$

$\begin{array}{lll}\text { Mean equation } & \text { Coefficient } & \text { t-statistic } \\ \mu & 0.0017 & 1.5196 \\ \operatorname{MA}(1) & 0.1893 & 4.1803 \star\end{array}$

Variance equation

$\begin{array}{lll}\omega & 0.0001 & 2.8118^{\star} \\ a_{1} & 0.0228 & 0.4726 \\ a_{2} & 0.3387 & 2.9968^{\star} \\ a_{3} & 0.4990 & 3.7119^{\star}\end{array}$

B. Post-futures period: $M A(1)-T G A R C H$

$\begin{array}{lrr}\text { Mean equation } & \text { Coefficient } & \text { t-statistic } \\ \mu & -0.0018 & -2.0068^{\star} \\ \text { MA(1) } & 0.1616 & 3.3140^{\star}\end{array}$

Variance equation

$\begin{array}{lll}\omega & 7.16 \mathrm{E}-05 & 2.9744 \star \\ a_{1} & 0.1364 & 1.7603 \star \\ a_{2} & 0.1486 & 0.9729 \\ a_{3} & 0.6114 & 6.4064 \star\end{array}$

* Significant at the 5 per cent level.

trading the SD falls slightly. This means that futures trading may not destabilise the underlying spot market. A more detailed empirical investigation needs to be carried out, however, using GARCH-volatility models.

\section{EMPIRICAL RESULTS}

\section{FTSE/ASE-20 index}

In Table 3, all GARCH models with a dummy variable are reported. There is a negative effect of futures trading on stock market volatility. The negative effect is statistically significant and, therefore, there is a decrease in volatility associated with the introduction of futures.

The results presented in Table 3 show that the introduction of FTSE/ASE-20 stock index futures has an effect on the volatility of the underlying spot market. This result is in line with the finding of
Bologna and Cavallo ${ }^{1}$ for the Italian Stock Exchange and Antoniou et al. ${ }^{23}$ for several stock indices from different countries.

The next step is to examine and compare the values of volatility parameters for the pre-futures and the post-futures periods.

The results from the MA(1)-TGARCH model are presented in Table 4. It is clear that some GARCH parameters are statistically significant at the 5 per cent level (with the exception of the ARCH parameter). In the pre-futures period, the news parameter is not statistically significant, while the leverage effect exists. Therefore, negative shocks have a greater impact on volatility. In the post-futures period, however, the leverage effect term is not significant, indicating that there is no asymmetric effect. The leverage effect changes from 0.3387 (pre-futures) to 0.1479 (post-futures). According to Table 4, there has been an increase in both $\mathrm{ARCH}$ and GARCH parameters. An increase in the 


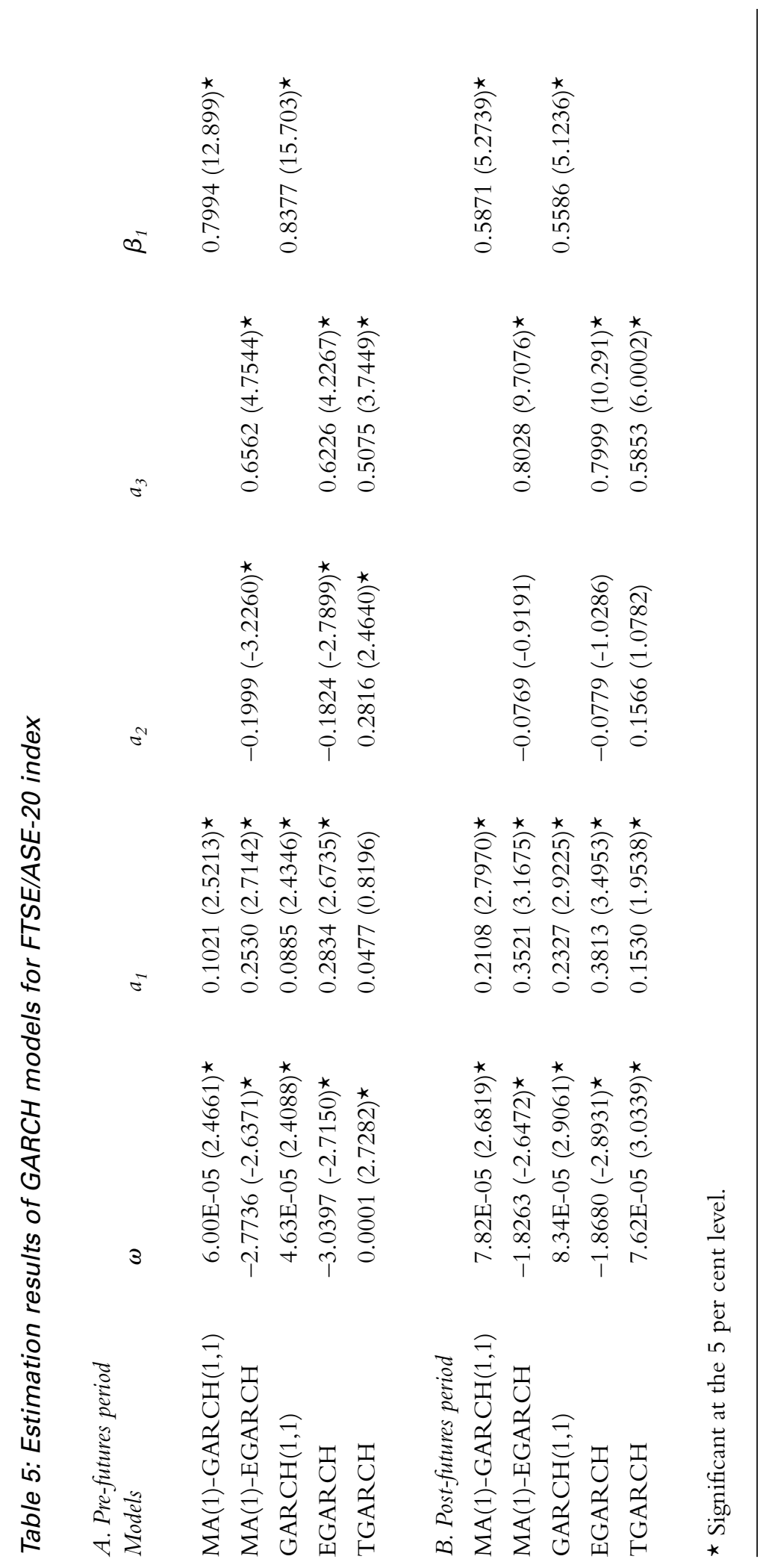


ARCH parameter suggests that good news has a greater impact. Also, an increase in the GARCH parameter indicates that old news has a greater persistent effect on price changes. Notice that similar findings arise from the TGARCH model.

The results from other GARCH models are presented in Table 5 for the pre-futures and post-futures period ( $t$-statistics in the parentheses).

Both GARCH(1,1) and MA(1)-GARCH $(1,1)$ reveal similar results. Specifically, all parameters are non-negative (and statistically significant), indicating that $\operatorname{GARCH}(1,1)$ models are well specified. ${ }^{38}$ Thus, there have been significant changes in the volatility structure of the FTSE/ASE-20 spot market after the introduction of futures trading. In addition, the evidence indicates an increase in the $\mathrm{ARCH}$ parameter, which suggests that news is reflected in prices more rapidly. Also, a decrease in the GARCH parameter suggests that old news has a less persistent effect on price changes. Therefore, old news will have a lower impact on today's price changes. The sum of the coefficients $a_{1}$ and $\beta_{1}$ changes from 0.9015 (pre-futures) to 0.7979 (post-futures) for the MA(1)-GARCH(1,1), and from 0.9262 (pre-futures) to 0.7913 (post-futures) for the simple GARCH $(1,1)$ model. Hence, the persistence of shocks from the pre-futures period to the post-futures period is reduced, indicating increased market efficiency. This is also confirmed by the reduction of the GARCH parameter $\left(\beta_{1}\right)$. Notice that, the difference in the sum of the GARCH coefficients is unlikely to be either statistically or economically significant. It is quite unlikely that 0.9015 is
Table 6: Results of GARCH models for FTSE/ASE MID 40 index

$\begin{array}{lcc}\text { Model } & \begin{array}{l}\text { Coeff. on } \\ \text { dummy }\end{array} & \text { t ratio } \\ \text { AR(3)-TGARCH } & 4.11 \mathrm{E}-05 & 1.7904^{\star} \\ \text { AR(3)-GARCH }(1,1) & -4.69 \mathrm{E}-07 & -0.0111 \\ \text { AR(3)-EGARCH } & 0.0461 & 2.3694 \text { } \\ \text { GARCH (1,1) } & -3.83 \mathrm{E}-05 & -0.6211 \\ \text { EGARCH } & -0.0133 & -0.2739 \\ \text { TGARCH } & -1.60 \mathrm{E}-05 & -0.3209\end{array}$

$\star$ Significant at the 5 per cent level.

statistically significant from 0.9262 . In the same line, the difference of the two coefficients is not economically significant. Nevertheless, the sign of MA(1) coefficient may be useful in capturing non-synchronous, infrequent trade in the FTSE-20 index.

From EGARCH $(1,1)$ models, there is an increase in $a_{1}$ and $a_{3}$ parameters. Also, the leverage effect term in both MA(1)-EGARCH(1,1) and EGARCH(1,1) models is negative. In the pre-futures period, the leverage effect term is statistically different from zero, indicating the existence of leverage in stock returns during the sample period. In the post-futures period, the leverage effect term is not significant.

\section{FTSE/ASE Mid 40 index}

Next, estimates of the effect of futures trading on stock market volatility for the FTSE/ASE Mid 40 index are reported. 
Table 7: FTSE/ASE MID 40 index AR(3)-TGARCH: dependent variable $R$

Mean equation Coefficient t-statistic Variance equation

A. Pre-futures period

$\begin{array}{lrcrrr}\mu & -0.0110 & -4.6507 \star & \omega & -1.53 \mathrm{E}-05 & -0.9185 \\ \operatorname{AR}(1) & 0.1501 & 1.1929 & a_{1} & -0.1797 & -1.0374 \\ \operatorname{AR}(2) & -0.3403 & -2.7025^{\star} & a_{2} & 0.5088 & 2.2920^{\star} \\ \operatorname{AR}(3) & -0.0972 & -0.9300 & a_{3} & 1.0449 & 6.2609 \star\end{array}$

B. Post-futures period

$\begin{array}{lrrrrr}\mu & -0.0039 & -3.4578^{\star} & \omega & 4.49 \mathrm{E}-05 & 1.9556^{\star} \\ \operatorname{AR}(1) & 0.1804 & 3.4773^{\star} & a_{1} & 0.0747 & 1.3070 \\ \operatorname{AR}(2) & -0.1454 & -2.4790^{\star} & a_{2} & 0.1655 & 1.6189 \\ \operatorname{AR}(3) & 0.0709 & 1.1719 & a_{3} & 0.7761 & 10.572^{\star}\end{array}$

$\star$ Significant at the 5 per cent level.

Table 6 shows that there is a positive effect of futures trading on stock market volatility based on the AR(3)-TGARCH(1,1) and AR(3)-EGARCH(1,1) models. This effect is statistically significant, and there is an increase in volatility associated with futures introduction. The other GARCH models indicate a decrease in volatility (ie negative effect). This effect is not statistically significant in all cases.

The results from the AR(3)-TGARCH(1,1) model are presented in Table 7. For this model, the leverage effect term is positive and statistically significant. So leverage exists, and there is an asymmetric effect to the news. In addition, the $a_{1}$ parameter changes from -0.1797 (pre-futures) to 0.0747 (post-futures). Nevertheless, both $t$ ratios indicate that these parameters are insignificant. The GARCH parameter $\left(a_{3}\right)$, however, decreases (from 1.0449 to 0.7761), indicating that old news has a less persistent effect on prices and, therefore, old news will have less impact on today's price changes.

For the TGARCH model, leverage is positive but not statistically significant. Also, both $\mathrm{ARCH}$ and GARCH parameter coefficients fall. This means good news has a relatively slow impact with low persistence (there is a decrease in $a_{3}$ ). Table 8 reports the estimation results of various GARCH models before and after the introduction of stock index futures.

For GARCH models, all parameters are non-negative, indicating the superiority of the $\operatorname{GARCH}(1,1)$ models. In both $\operatorname{AR}(3)-\operatorname{GARCH}(1,1)$ and $\operatorname{GARCH}(1,1)$, there is a decrease in the ARCH parameter, which suggests that news is being reflected in prices slowly. The 


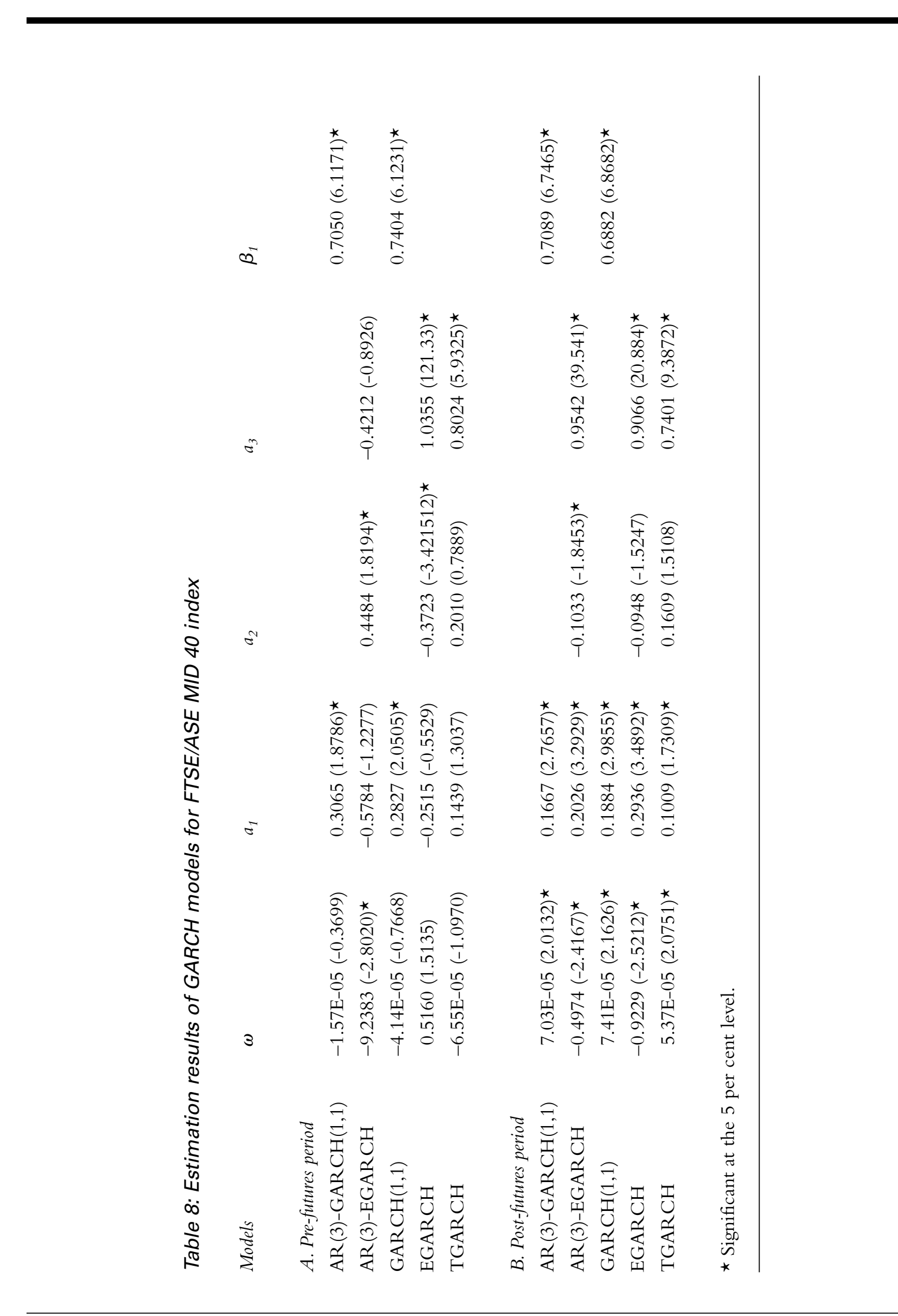


ARCH coefficient parameters are statistically significant, but estimates of the GARCH parameters differ. For $\operatorname{AR}(3)-\operatorname{GARCH}(1,1)$, there is increase in the GARCH parameter (from 0.7050 to 0.7089), which suggests that old news has a greater persistent effect on price changes. For the simple $\operatorname{GARCH}(1,1)$ model, the reduction of the GARCH parameter suggests that old news has a less persistent effect, and that old news has a lower impact on today's price changes. Also, as for the FTSE/ASE-20 index, the sum $a_{1}+\beta_{1}$ reduces from 1.0116 (pre-futures) to 0.8756 (post-futures) for the AR(3)-GARCH $(1,1)$ and from 1.0232 (pre-futures) to 0.8766 (post-futures) for the simple GARCH $(1,1)$ model. Therefore, there is an increase in market efficiency. In all cases, the coefficient parameters are statistically significant.

Finally, EGARCH models give interesting information about the futures trading effect. In particular, for AR(3)-EGARCH, the leverage effect term changes from 0.4484 to -0.1033 . For the simple EGARCH model, the leverage effect term changes from -0.3723 to -0.0948 . Notice that in the pre-futures period, $a_{2}<0$ and significant, indicating that a leverage effect exists in stock returns during the sample period. Hence, a negative shock increases the conditional variance.

\section{Unconditional variance}

In most GARCH $(1,1)$ models, the ARCH and GARCH parameters are non-negative. Also since the sum $a_{1}+1$ for the GARCH $(1,1)$ model is less than one, the models have finite unconditional variances (see also Bologna and Cavallo ${ }^{1}$ ). The unconditional variance $\left(\sigma^{2}\right)$ has the form

$$
\sigma^{2}=\frac{\omega}{1-a_{1}-\beta_{1}}
$$

Comparing parameters across the two sub-periods, it is found that for the FTSE/ASE-20 contract there is an increase in the ARCH parameter, while the GARCH parameter decreases. Now, for the MA(1)-GARCH(1,1) model, the unconditional variance is equal to 0.000609651 for the pre-futures period and 0.000387044 for the post-futures period. In addition, for the simple $\operatorname{GARCH}(1,1)$ model, the unconditional variance is equal to 0.000628171 for the pre-futures period and 0.000399753 for the post-futures period. In other words, the unconditional variance in the post-futures period is lower than that in the pre-futures period. This indicates lower market volatility after the introduction of stock index futures in the Greek stock market.

For the FTSE/ASE Mid 40 index, the unconditional variance is still lower in the post-futures period. More specifically, for the AR(3)-GARCH(1,1) model, the unconditional variance is equal to 0.001347408 for the pre-futures period and 0.000565422 for the post-futures period. Also, for the simple $\operatorname{GARCH}(1,1)$ model, the unconditional variance changes from 0.001898816 to 0.000600954 . Thus, the unconditional variance in the post-futures period is lower than that of the pre-futures period. In other words, the volatility of the Greek stock market diminished after the introduction of stock 
Figure 1: Effect of a $1 S D$ shock on spot price volatility before the onset of futures trading (FTSE/ASE-20)

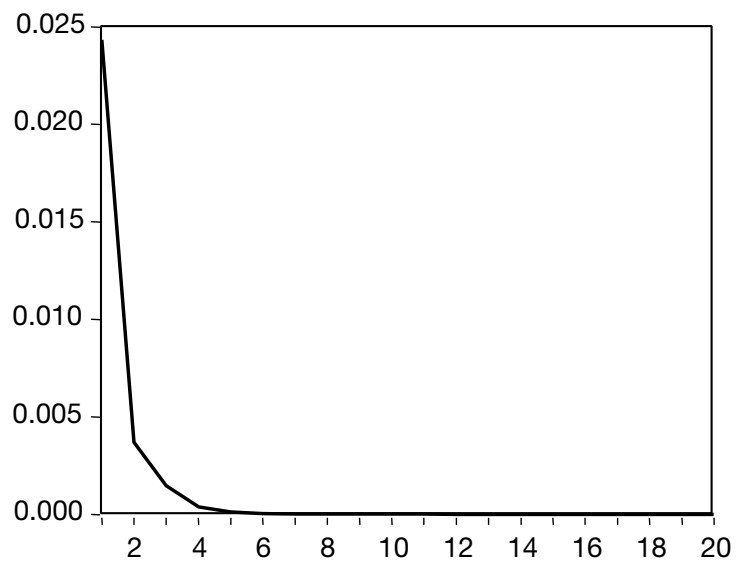

Figure 2: Effect of a $1 S D$ shock on spot price volatility after the onset of futures trading (FTSE/ASE-20)

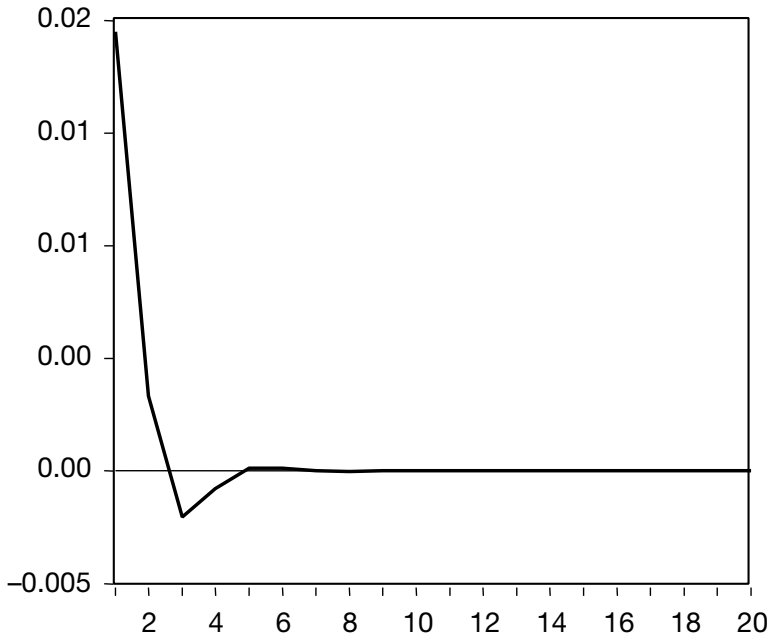

index futures trading.

This finding is in line with what Bologna and Cavallo ${ }^{1}$ found for the Italian stock market. Finally, the impact of futures trading on the rate at which information is incorporated into spot prices is illustrated, and the effect of the shock to both the pre- and post-futures periods is plotted.

Figures 1 and 2 plot the effect of the shock for the FTSE/ASE-20, and Figures 3 and 4 plot the effect of the shock for the FTSE/ASE Mid 40. From these figures it is 
Figure 3: Effect of a $1 S D$ shock on spot price volatility before the onset of futures trading (FTSE/ASE Mid 40)

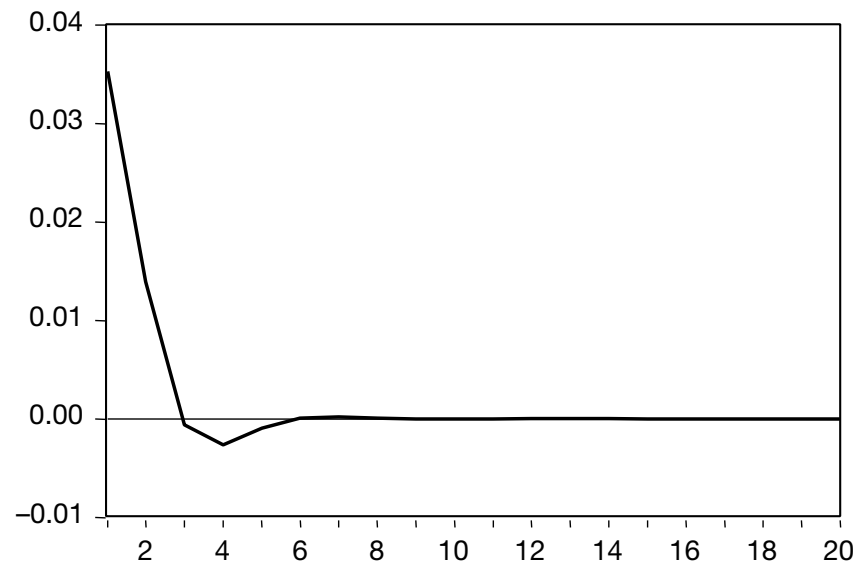

Figure 4: Effect of a $1 S D$ shock on spot price volatility after the onset of futures trading (FTSE/ASE Mid 40)

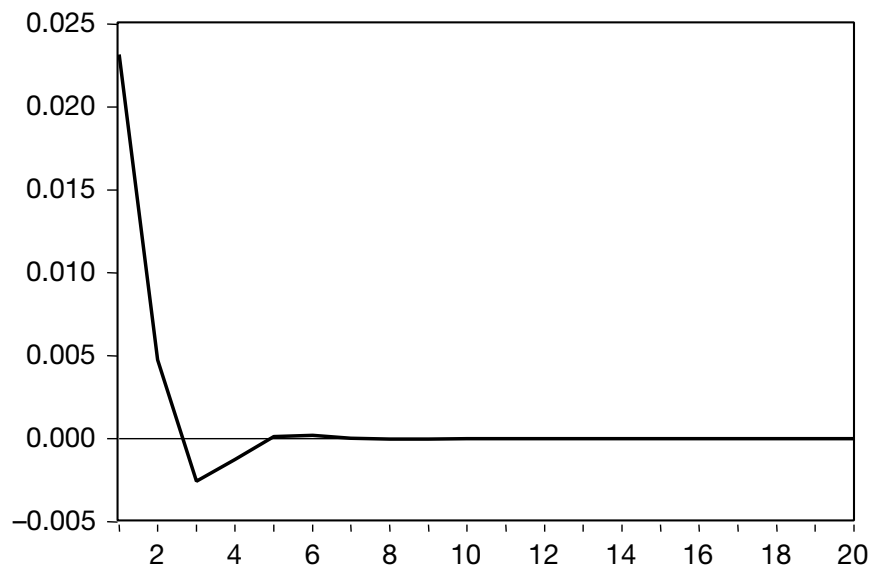

clear that the impact of the shock is more persistent in the post-futures period than in the pre-futures period for both indices.

\section{SUMMARY AND CONCLUSIONS}

The introduction of a futures market and, in particular, the impact of futures on stock market volatility has generated a long debate. Previous studies have shown that the futures market leads to an increase in market depth and a decrease in volatility. This is due to the more rapid rate at which information is reflected in prices and 
speculation. Other studies suggest that a decrease in cash market volatility is due to an increase in market liquidity. Empirical studies for UK and US financial markets do not conclude clearly whether the introduction of futures stabilises or destabilises the underlying spot market.

This study has analysed the effect of the impact of the introduction of futures on other stock prices on the Greek Stock Exchange. To the authors' knowledge, this is the first study that has examined the effect of the Greek futures market on stock market volatility.

A significant indicator of this effect is spot market volatility. To analyse the relationship between stock index futures and stock market volatility, several GARCH models were used to model the FTSE/ASE-20, FTSE/ASE Mid 40 and General ASE indexes.

For the FTSE/ASE-20, the results of the effect of futures trading suggest that there has been a negative effect on spot price volatility during the period. For the sub periods, we find that good news has a more rapid impact on stock return volatility, and that the persistence of shocks is reduced, indicating increased market (pricing) efficiency. This is not surprising, as the FTSE/ASE-20 futures market is highly liquid. In addition, the results suggest that old news has either a greater or a less-persistent effect on price changes. The fact that noise traders ${ }^{39}$ are the principal users of the FTSE/ASE-20 contract indicates that volatility becomes more persistent, so an increase in persistence is not surprising. Further, GARCH $(1,1)$ models show that futures trading improves the speed of information flow to the spot market. This is in line with arguments from Antoniou and Holmes ${ }^{7}$ for the FTSE 100 index.

For the FTSE/ASE Mid 40 index, the empirical results are mixed. Asymmetric AR(3)-EGARCH and AR(3)-TGARCH models show a positive effect on price volatility during the period examined. GARCH-type models (where the conditional mean equation just includes a constant term) show a negative (but not significant) effect, however. Furthermore, there has been a decrease in both the $\mathrm{ARCH}$ and GARCH parameters, indicating that news is being reflected in prices more slowly, and that old news has a less persistent effect on prices. The decrease in the coefficient on past variance shows that, after the onset of futures trading, spot market volatility is not important to spot market participants (see Antoniou and Foster ${ }^{18}$ ). The main reason is that the onset price risk can be hedged in the futures market. Further, the TGARCH and EGARCH specifications show that the leverage effect exists and, thus, there is an asymmetric effect to the news. Also, the EGARCH model shows that a negative shock increases the conditional variance.

In summary, the evidence suggests a negative effect of futures trading on Greek stock market volatility (however, this is not very strong for FTSE/ASE Mid 40 index).

This is confirmed by the estimation of three different types of GARCH specifications and unconditional variances. In particular, the unconditional variance in the post-futures period is found to be lower than that of the pre-futures period. This 
indicates lower market volatility after the introduction of stock index futures. This is consistent with Bologna and Cavallo ${ }^{1}$ for the Italian Stock Exchange.

Finally, future research should test (1) whether the introduction of stock index futures affects the volume-volatility relationship in the spot market, using GARCH and other stochastic volatility models, and (2) for the presence of causal relationships, using VAR representation and Granger causality tests.

\section{References and Notes}

1 Bologna, P. and Cavallo, L. (2002) 'Does the Introduction of Stock Index Futures Effectively Reduce Stock Market Volatility? Is the 'Futures Effect' Immediate? Evidence from the Italian Stock Exchange using GARCH', Applied Financial Economics, Vol. 12, pp. 183-192.

2 S. Kyle (1985 'Continuous Auctions and Insider Trading', Econometrica, Vol. 53, pp. 1315-1335) defines market depth as the order flow required to move prices by one unit. Market depth is related to non-informational trading activity and provides additional information about the interaction between price volatility and trading volume.

3 Stein, J. (1987) 'Informational Externalities and Welfare-reducing Speculation', Journal of Political Economy, Vol. 95, pp. 1123-1145.

4 Subrahmanyam, A. (1991) 'A Theory of Trading in Stock Index Futures', Review of Financial Studies, Vol. 4, pp. 17-51.

5 Newbery, D. M. (1987) 'When Do Futures Destabilize Spot Prices?', International Economic Review, Vol. 28, pp. 291-297.

6 Chari, V. V., Jagannathan, R. and Jones, L. (1990) 'Price stability and futures trading in commodities', Quarterly Journal of Economics, Vol. 105, pp. 527-34.

7 Antoniou, A. and Holmes, P. (1995) 'Futures Trading, Information and Spot Price Volatility: Evidence for the FTSE 100 Stock Index Futures Contract using GARCH', Journal of Banking \& Finance, Vol. 19, pp. 117-129.

8 Hodgson, A. and Nicholls, D. (1991) 'The Impact of Index Futures Markets on Australian Sharemarket Volatility', Journal of Business Finance
E Accounting, Vol. 18, pp. 267-280.

9 Edwards, F. R. (1988) 'Futures Trading and Cash Market Volatility: Stock Index and Interest Rate Futures', Journal of Futures Markets, Vol. 8, pp. 421-439.

10 Chang, E. C., Cheng, J. and Pinegar, J. M. (1999) 'Does Futures Trading Increase Stock Market Volatility? The Case of the Nikkei Stock Index Futures Markets', Journal of Banking and Finance, Vol. 23, pp. 727-753.

11 Aggarwal, R. (1988) 'Stock Index Futures and Cash Market Volatility', Review of Futures Markets, Vol. 7, No. 2, pp. 290-299.

12 Harris, L. (1989) 'S\&P500 Cash Stock Price Volatilities', Journal of Finance, Vol. 44, pp. 1155-1175.

13 Lockwood, L. J., and Linn, S. C. (1990) 'An Examination of Stock Market Return Volatility During Overnight and Intraday Periods 1964-1989', Journal of Finance, Vol. 45, pp. 591-601.

14 Maberly, E. D., David, S. A. and Roy, R. G. (1989) 'Stock Index Futures and Cash Market Volatility', Financial Analysts Journal, Vol. 45, pp. 75-77.

15 Chang, E., Jain, P. and Locke, P. (1995) 'Standard \& Poor's 500 Index Futures Volatility and Price Changes Around the New York Stock Exchange Close', Journal of Business, Vol. 68, pp. 61-84.

16 Chang, E., Chou, R. and Nelling, E. (2000) 'Market Volatility and the Demand for Hedging in Stock Index Futures', Journal of Futures Markets, Vol. 20, pp. 105-125.

17 Chan, K., Chan, K. C., and Karolyi, G. A. (1991) 'Intraday Volatility in the Stock Index and Stock Index Futures Markets, Review of Financial Studies, Vol. 4, pp. 657-684.

18 Antoniou, A. and Foster, A. J. (1992) 'The Effect of Futures Trading on Spot Price Volatility: Evidence for Brent Crude Oil Using GARCH', Journal of Business Finance \& Accounting, Vol. 19, No. 4, pp. 473-484.

19 Brorsen, B. W. (1991) 'Futures Trading, Transaction Costs, and Stock Market Volatility', Journal of Futures Markets, Vol. 11, pp. 153-163.

20 Gulen, H. and Mayhew, S. (2000) 'Stock Index Futures Trading and Volatility in International Equity Markets', Journal of Futures Markets, Vol. 20, pp. 661-685.

21 Holmes, P. (1996) 'Spot Price Volatility, Information and Futures Trading: Evidence from a Thinly Traded Market', Applied Economics Letters, Vol. 3, pp. 63-66.

22 Robinson, G. (1993) 'The Effects of Futures 
Trading on Cash Market Volatility: Evidence from the London Stock Exchange', Bank of England, Working Paper, Series No 19.

23 Antoniou, A., Holmes, P. and Priestley, R. (1998) 'The Effects of Stock Index Futures Trading on Stock Index Volatility: An Analysis of the Asymmetric Response of Volatility to News, Journal of Futures Markets, Vol. 18, pp. 151-166.

24 Butterworth, D. (1998) 'The Impact of Futures Trading on Underlying Stock Index Volatility: The Case of the FTSE Mid 250 Contract', Working Paper, Department of Economics, University of Durham.

25 Rahman, S. (2001) 'The introduction of derivatives on the Dow Jones Industrial Average and their impact on the volatility of component stocks', Journal of Futures Markets, Vol. 21, pp. 633-653.

26 Koutmos, G. and Tucker, M. (1996) 'Temporal Relationships and Dynamic Interactions Between Spot and Futures Stock Markets', Journal of Futures Markets, Vol. 16, pp. 55-69.

27 Pericli, A. and Koutmos, G. (1997) 'Index Futures and Options and Stock Market Volatility', Journal of Futures Markets, Vol. 17, pp. 957-974.

28 Darrat, A. F., Rahman, S. and Zhong, M. (2000) 'On the role of futures trading in sport market fluctuations: Perpetrator of volatility or victim of regret?', Paper Presented at Financial Management Association International 2000 Annual Meeting, Seattle, Washington.

29 Lien, D. and Tse, Y. K. (1999) 'The Effects of Cash Settlement on the Cash-Futures Prices and Their Relationship: Evidence from the Feeder Cattle Contract', Working Paper, University of Kansas.

30 Kyriacou, K. and Sarno, L. (1999) 'The Temporal Relationship between Derivatives Trading and Spot market Volatility in the U. K.: Empirical Analysis and Monte Carlo Evidence', Journal of Futures Markets, Vol. 19, pp. 245-270.

31 Pilar, C. and Rafael, S. (2002) 'Does Derivatives Trading Destabilize the Underlying Assets? Evidence from the Spanish Stock Market', Applied Economics Letters, Vol. 9, pp. 107-110.
32 Figuerola-Ferretti, I. and Gilbert, C. L. (2001) 'Has Futures Trading Affected the Volatility of Aluminium Transaction Prices?', Working Paper, Department of Economics, Queen Mary, University of London.

33 Chiang, M.-H. and Wang, C.-Y. (2002) 'The Impact of Futures Trading on Spot Index Volatility: Evidence for Taiwan Index Futures', Applied Economics Letters, Vol. 9, pp. 381-385.

34 Bae, S. C., Kwon, T. H. and Park, J. W. (2004) 'Futures Trading, Spot Market Volatility, and Market Efficiency: the Case of the Korean Index Futures Markets', Journal of Futures Markets, Vol. 24, pp. 1195-1228.

35 Ryoo, H.-J. and Smith, G. (2004) 'The Impact of Stock Index Futures on the Korean Stock Market', Applied Financial Economics, Vol. 14, pp. 243-251.

36 Antoniou, A., Koutmos, G. and Pericli, A. (2005) 'Index Futures and Positive Feedback Trading: Evidence from Major Stock Exchanges', Journal of Empirical Finance, Vol. 12, pp. 219-238.

37 Floros, C. and Vougas, D. V. (2004) 'Hedge Ratios in Greek Stock Index Futures Market', Applied Financial Economics, Vol. 14, No. 15, pp. 1125-1136.

38 The $\operatorname{GARCH}(1,1)$ model has been found to be the most parsimonious representation of conditional variance that best fits many financial series, see Bollerslev, ${ }^{39}$ Butterworth, ${ }^{24}$ Antoniou and Holmes ${ }^{7}$ and Bologna and Cavallo. ${ }^{1}$

39 Bollerslev, T. (1987) 'A Conditional Heteroscedastic Time Series Model for Speculative Prices and Rates of Return', Review of Economics and Statistics, Vol. 69, pp. 542-547.

40 A noise trader is a trader who trades for pleasure or who trades on information that he or she believes is valuable but which is not useful. Noise traders can be treated as investors who do not use fundamental information or who otherwise fail to use it 'fully and correctly'. G. W. Schwert (1990 'Stock Volatility and the Crash of '87', Review of Financial Studies, Vol. 3, pp. 77-102) suggests that noise traders are more active in futures than in spot markets. 


\section{APPENDIX 1}

A. GARCH variance series before and after the introduction of the FTSE/ASE-20 stock index futures
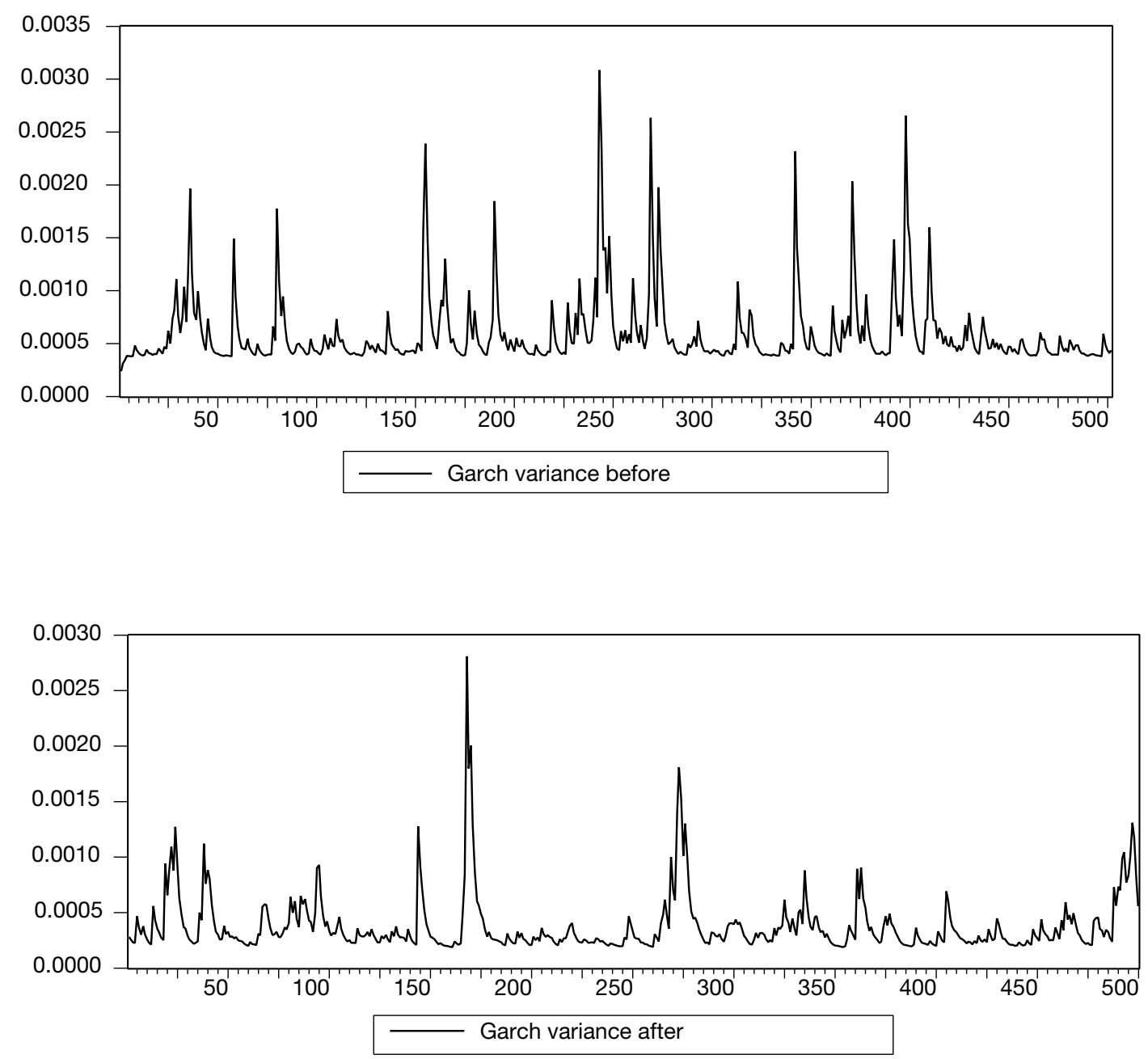
B. GARCH variance series before and after the introduction of the FTSE/ASE Mid 40 stock index futures
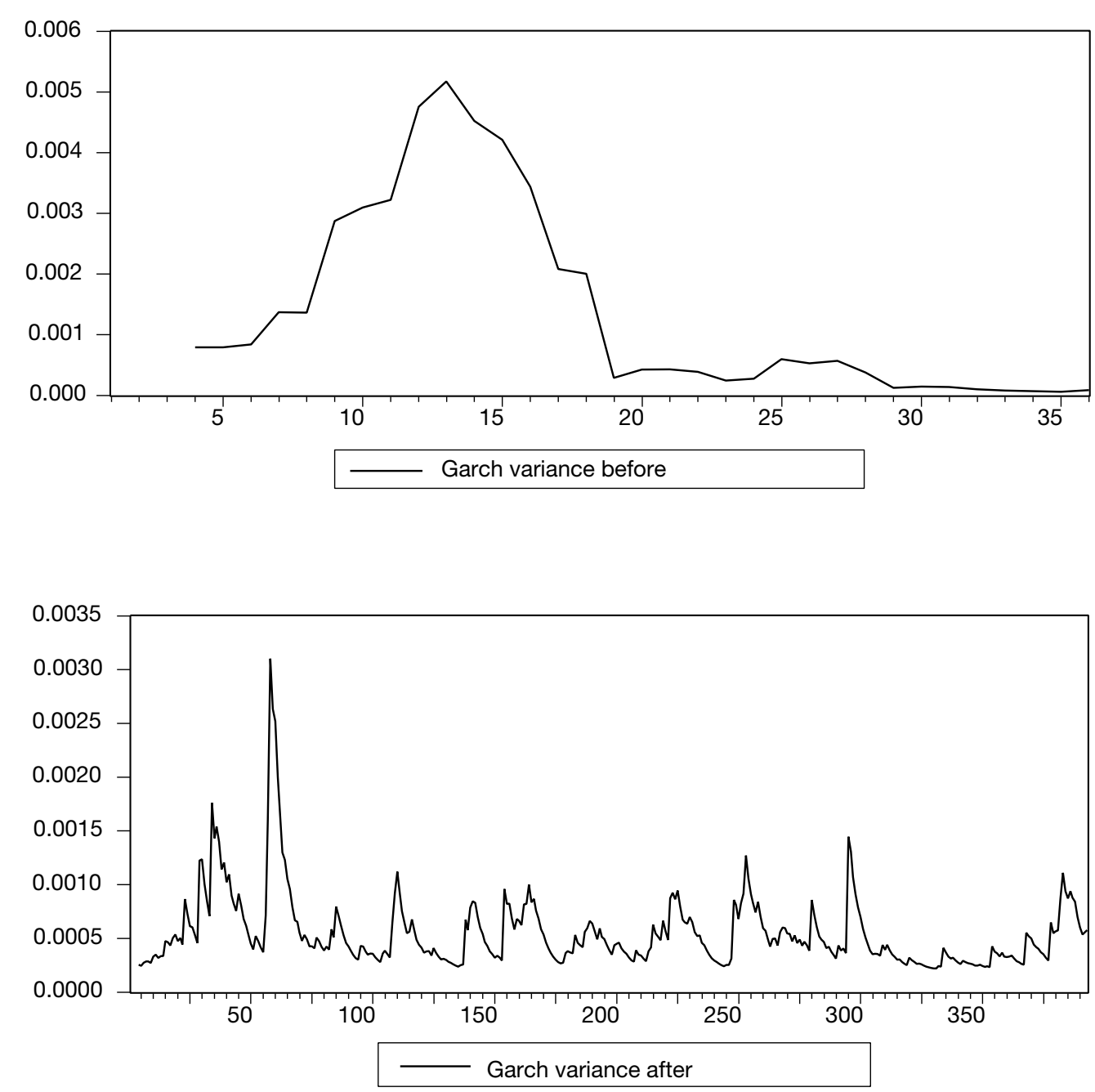